\title{
FACTORS INFLUENCING GREEN PURCHASING ADOPTION FOR SMALL AND MEDIUM ENTERPRISES (SMES) IN MALAYSIA
}

\author{
Pavitra Ramakrishnan \\ Keysight Technologies \\ Hasnah Haron \\ Universiti Sains Malaysia \\ Yen-Nee Goh* \\ Universiti Sains Malaysia
}

\begin{abstract}
Acute awareness of environmental problems following continuous environmental deterioration drives growing SMEs to adopt green purchasing practices. SMEs are recognized as the main source of environmental risk and bottleneck in adopting green purchasing practices. This is mainly due to SMEs are lack of information and resources or expertise to deal with the environmental issues. Therefore, this study aimed to investigate the factors influencing green purchasing adoption for EMS IS0 14001 SMEs in Malaysia. A cross-sectional approach using survey was conducted among all the EMS 14001 certified SMEs listed under the Federation of Malaysian Manufacturers (FMM) 2012 directory. A research model been proposed as supported with stakeholders theory. The research model comprises of green purchasing adoption as a dependent variable while government regulations, customer pressures, top management support, supplier relationship and perceived benefits as independent variables and corporate social responsibility as moderating variable. Results show that only government regulations, customer pressures and perceived benefits were found to be positively and significantly influencing green purchasing adoption for SMEs in Malaysia. Limitations and suggestion for future research are discussed.
\end{abstract}

Keywords: Green Purchasing Adoption; SMEs; Malaysia..

\section{INTRODUCTION}

Industrial development has always created inestimable wealth and prosperity. However, this benefit for the humanity has also been accompanied by unintentional environmental degradation to our planet, the Earth. Business organizations are identified as the main source of environmental degradation and expected to adopt green practices in the supply chain process

^ Corresponding author: Graduate School of Business, Universiti Sains Malaysia, 11800, Penang, Malaysia. Email: gohyennee@ gmail.com, Tel: 04-6535294. 
(Baguette, 2009). This has introduced the practice of Green Supply Chain Management (GSCM), integrating environment thinking into supply chain management, including product design, material purchasing and selection, manufacturing processes, delivery of the final product to the customers and end of life management of the product after its useful life (Srivastara, 2007). In the process of GSCM, material purchasing is the most important process prior to manufacturing activities by business organization, where purchasing role highlighted an effective environmental management which demands for the emergence of Green Purchasing (GP) (Handfield et al. 2002). Chien \& Shih (2007) defines green purchasing as a responsible purchasing process that accounts environmental and social consequences, where it involves activities that reduce, reuse or recycle materials that express environmental preferences through the supply chain. Currently, there is an increase number of SMEs showing interest in the implementation of EMS ISO 14001. This shows that they are cognizant on its firm environmental impacts and simultaneously is determined to gain variety of benefits through the implementation of EMS ISO 14001 (Goh, 2011).

This paper focused on the green purchasing adoption by EMS 14001 certified SMEs as they are expected to embark on green purchasing initiatives. It is noticed that the larger companies where the headquarters are from United States of America (USA), United Kingdom (UK), Japan and other European countries have taken steps to promote the green initiatives or practice whereas the local manufacturing industries, like SMEs are still not adopting the green purchasing practice and having the attitude of "wait and see" (Green Purchasing Network Malaysia, 2003). This attitude would be the main reason for Malaysian companies to still stay far behind in adopting the green purchasing practices compared to foreign countries (Green Purchasing Network Malaysia, 2003). SMEs represent 99.2\% of all businesses in Malaysia and contribute $56.4 \%$ of total employment in the country, SMEs constitute an important component of the Malaysian economy and have the potential to be a powerful engine of growth and innovation (Tenth Malaysia Plan, 2010). SMEs role is extremely important in an attempt to improve the current environmental situation.

\subsection{Problem statement}

Business organizations should be the back bone of the society in saving our environment by spearheading the green practices due to the size and visibility of these companies (ElTayeb et al. 2009). However, manufacturing companies are actually deteriorating the environment and ecology severely with irreversible impacts in consideration of the enormous amount of un-recyclable resources consumed. Lee and Chen (2010) have identified $70 \%$ of pollutants on Earth are discharged by manufacturing industry which might cause severe destruction towards environment such as global warming, ozone depletion and air pollutions. According to an estimate as stated in Green Purchasing Network Malaysia (2003), in the 1990s, the average solid waste disposal by Malaysia was $0.7 \mathrm{~kg}$ per day and today the solid waste disposal of Malaysia has risen to about $2.2 \mathrm{~kg}$ per day. Most of this solid waste disposal is believed to be from the manufacturing industry. If this trend continues, there will be severe destruction towards environment issues. Experts do believe that, a landfill can last 10 years longer if Malaysians recycled 50\% of their solid waste (Green Purchasing Network Malaysia, 2003). Therefore, it is extremely important for the manufacturing industry, especially SMEs 
to adopt green purchasing practices to save both the environment and the society, as SMEs are recognized as the major contributor towards the GDP of the country (Green Purchasing Network Malaysia, 2003).

Malaysian fully owned firms have the lowest level of participation in the green initiatives compare to foreign based companies (ElTayeb et al. 2009). One of the reasons that Malaysian owned firm having the lowest participation in GP is because it is still a very new concept in Malaysia (Green Purchasing Network Malaysia, 2003). Lee (2008) added that SMEs usually lack information resources or expertise to deal with the environmental issues. Therefore, SMEs are recognized as the main source of environmental risk and bottleneck in pursuing the goal of green supply chain management (Goh \& Zailani, 2010). According to Goh and Zailani (2010), with the increasing trend of global environment protection awareness, SMEs in Malaysia will be out of the competition if green initiatives is not adopted in their business strategy. The empirical studies on green purchasing are considered low as the drivers for green purchasing adoption is not given importance in the previous studies (Chien \& Shih, 2007; ElTayeb et al. 2009; Hsu \& Hu, 2008; Srivastara, 2007).

Hence, it is crucial to investigate factors which influence companies to adopt green purchasing practices. Therefore, this study aimed to fill the gap in the literatures by investigating factors influencing Green Purchasing (GP) adoption for EMS 14001 certified Small and Medium Enterprises (SMEs) in Malaysia. Hence, it is believed that the results from this study would serve as a useful model for SMEs in Malaysia in getting better understanding on influencing factors (i.e. government regulations, customer pressures, top management support, supplier relationship, perceived benefits, corporate social responsibility) and its significant relationship towards Green Purchasing (GP) adoption.

\subsection{Research questions}

Based on the problem statement, this study intends to answer the following research questions:

1. What are the factors influencing Green Purchasing (GP) adoptions among SMEs in Malaysia?

2. Does corporate social responsibility moderate the relationship between government regulations, customer pressures, top management support, supplier relationship and perceived benefits towards Green Purchasing (GP) adoption for SMEs in Malaysia?

\section{LITERATURE REVIEW}

\subsection{Green Purchasing Adoption}

Green purchasing (GP) is an environmental purchasing consisting of involvement in activities that include the reduction, reuse, recycling of materials in the process of purchasing (Chien and Shih, 2007; Ninlawan et al. 2010). Min and Galle (2001) defined GP as an environmentallyconscious purchasing practices that reduces sources of waste and promotes recycling ad 
reclamation of purchased materials without adversely affecting the performance requirements of such materials. According to Salam (2008), GP is a concept of acquiring a selection of products and services that minimizes environmental impact. Based on these few definition of GP, GP can be summarized as preference of the organization to purchase products from suppliers who are environmentally conscious and also its efforts to ensure that its purchased products have environmentally friendly attributes. In simple word, GP can be describe as adding environmental aspects to price and performance criteria when making the purchasing decisions with a ultimate goal which is to reduce environmental impacts of sourcing and to increase resource efficiency.

An organization that want to adopt the GP practices should take the opportunity to review their business processes along the supply chain to identify if a more environmentally sound approach would help to cure the inefficiencies that occur in the supply chain. However, since the concept of GP is still a new in Malaysia and there is a lack of empirical studies on GP in Malaysia, thus there are still a lot of companies in Malaysia still behind and yet to adopt the GP concept (ElTayeb et al. 2009). Although, the study by Rao (2006) investigates the existence of GP based on a sample of 52 companies taken from five different countries which includes Philippines, Indonesia, Malaysia, Thailand and Singapore, but it is difficult to draw a valid and reliable conclusion from it for Malaysia. Numerous studies also support that adopting green purchasing can reduce the cost, increase efficiency, eliminate waste and pollution, and generate brand reputation (Duber-Smith, 2005; Gunther, 2006; Stevels, 2002).

\subsection{Government Regulations}

Business organizations are expected to adopt GP in order to comply with environmental regulations set by regulatory institutions, mainly government bodies in the country (ElTayeb et al. 2009). Based on the research conducted by Holt \& Ghobadian (2009), the influence of UK's current environmental legislation has the highest influence for company to initiate GP initiatives. The results from various studies also conclude that government regulations exert the most perceived pressure on manufacturing organizations and states a significant positive relationship on GP (Ghobadian et al. 2001; Logamuthu \& Zailani, 2010; Preuss, 2001; Zhu \& Geng, 2001). Regulations are expected to encourage the business organizations to follow the environmental practices and adopt the GP initiatives. If regulations are adequately enforced, then there is a higher chance of GP adoption among business organizations in Malaysia.

\subsection{Customer Pressures}

Customers have exerted pressure on their suppliers to achieve better environmental performance, resulting in greater motivation for suppliers to cooperate with customers for environmental objectives ( $\mathrm{Hsu} \& \mathrm{Hu}, 2008$ ). Customers are major financial stakeholders who can exert considerable pressures and demand goals of from suppliers to adopt GP to achieve sustainability or environmental performance (Doonan et al. 2005; Lin, 2007; Peng \& Lin, 2008). Customers are the most important and influential stakeholders for the suppliers. Therefore, changes in procurement policies and practices of a customer, which in turn appear as environmental requests, can directly affect the behavior of its suppliers by serving as an 
instigator in making them turn their attention to environmental issues (Lee, 2008). There are also empirical research about the relationship between GSCM with customer's requirement (Simpson et al. 2007).

\subsection{Top Management Support}

Top management support is an important driver towards the GP adoption (Lin \& Ho, 2011). Top management includes senior managers and Chief Executive Officers (CEOs) in the companies (Holt \& Ghobadian, 2009; Hsu \& Hu, 2008). GP require the collaboration and coordination of different departments and divisions during adoption. Top management motivates and support employees in GP adoption. For example, top management may provide training, incentive or rewards to encourage the GP adoption by employees as employees are the most important factor which contributes to the successful of GP adoption by any companies. Handfield et al. (2005) argued that top management at the company should recognize the importance of environmental issues in the supply chain to enhance the GP adoption. Hsu and $\mathrm{Hu}(2008)$ stated commitment of senior managers is extremely conducive to the implementation and adoption stages for GP, because without such top management commitment most programs are bound to fail. All the GP practices are integrative and require cross-functional cooperation rather than simply being oriented to a single function or department.

\subsection{Supplier Relationship}

Supplier relationship as an organizational collaboration with suppliers to produce environmental friendly products which does not contain hazardous or toxic chemicals (Bowen et al. 2001). This is because the disruption risks engendered by environmental issues can pass on through suppliers. The study by $\mathrm{Hsu} \& \mathrm{Hu}(2010)$ results that practicing GP and establishing environmental requirements for purchasing items can ensure product environmental quality. Walton et al. (1998) examine the integration of suppliers into environmental management processes and suggests that organizations need to involve suppliers and purchasers in improving the environmental performance of the whole supply chain, and thus addressing the purchasing function's impact on the environment.

\subsection{Perceived Benefits}

In general, it is well established that business organizations' main objectives are on maximizing their profit and financial returns. Every single aspect of their decision is evaluated based on the cost-benefit criteria. Environmental initiatives are expected to conform to this general rule, for example, a business perceived benefits must be generated from green initiatives before it engage itself into the initiatives of making profits (Goh et al. 2006). However, it is not the real situation now as firms are fighting to achieve competitive advantage and to become a market leader in anyways that they can make profit with less consideration towards environmental and social aspects. Organizations adoption towards GP practices would increase if they identify that this will result in specific financial and operational benefits (Bowen et al. 2001). 


\subsection{Corporate Social Responsibility}

In the previous research, numerous studies have investigated corporate social responsibility (CSR) as an independent variable towards the GP adoption and they found a significant relationship between CSR and GP (Forman \& Jorgensen, 2004; Murphy \& Poist, 2003; Preuss, 2001). However, given in the Malaysian context, CSR was found to have no direct significant relationship effect on GP (ElTayeb et al. 2009). The results indicate that CSR does not directly motivate or influence the firm towards GP adoption. This is supported by Min \& Galle (2001) who stated that green initiatives require considerable cost and capabilities, where the firm would consider other factors which directly motivates the firm to adopt GP practices, where by CSR is just seen as a moderator to enhance the GP adoption by firms. SMEs need a financial assistance to engage into GP practices, which is mainly given and supported by the government, and they would also seek for a cost benefit criteria as what would be their return through the GP adoption. This is added, where Malaysian firms are directly motivated towards GP adoption by main factors such as regulation, customer pressures and expected business benefit, where the high sense of social responsibility would motivate the main factors towards the higher level of GP adoption (Milton, 2008).

\subsection{Stakeholders Theory}

Stakeholder is "any group or individual who can affect or is affected by the achievement of an organization's objectives, where those groups who are vital to the survival and success of the corporation" (Freeman, 2004). Stakeholder theory suggests that firms produce externalities that affect many parties (stakeholders) who are important to the firm. Externalities often cause stakeholders to increase pressures on companies to reduce negative impacts and increase positive ones such as saving our environment from pollution (Sarkis et al. 2010). The groups of stakeholders include customers, employees, local communities, suppliers and distributors, shareholders, media, the public in general, business partners, future generations, past generations (founders of organizations), academics, competitors, non-government organizations (NGOs) or activists, stakeholder representatives such as trade unions or trade associations of suppliers or distributors, financiers other than stockholders, government, regulators and policymakers (Friedman \& Miles, 2006).

This is added with the pillar of stakeholder theory which suggests that the company decisions which affect stakeholder outcomes has to be ethical (Fontaine, Haarman, \& Schmid, 2006). In this kind of situation, when the action of an agent affects the other agent, the company has to build ethics principles (Fontaine et al. 2006). Decisions made by the company without any consideration of their impact are usually thought to be unethical (Fontaine et al. 2006). Firm has to act as a vehicle for coordinating stakeholders interests, where the firm should be managed for the perceived benefits of its stakeholders. Stakeholders should participate in decisions that substantially affect their welfare and managers must act in the interests of the stakeholders, as their agent in the interests of the corporation to ensure the survival of the firm (Evan \& Freeman, 1990).

This clearly indicates that a stakeholder approach is justified in the development of environmental strategies, towards GP adoption. Thus, this study adopts the stakeholder theory 
which suits the model of this study consist of independent variables such as government regulations, customer pressures, top management support, supplier relationship and perceived benefits and moderating variable, corporate social responsibility in investigating the dependent variable, the green purchasing adoption among SMEs in Malaysia.

Figure 1: Theoretical Framework

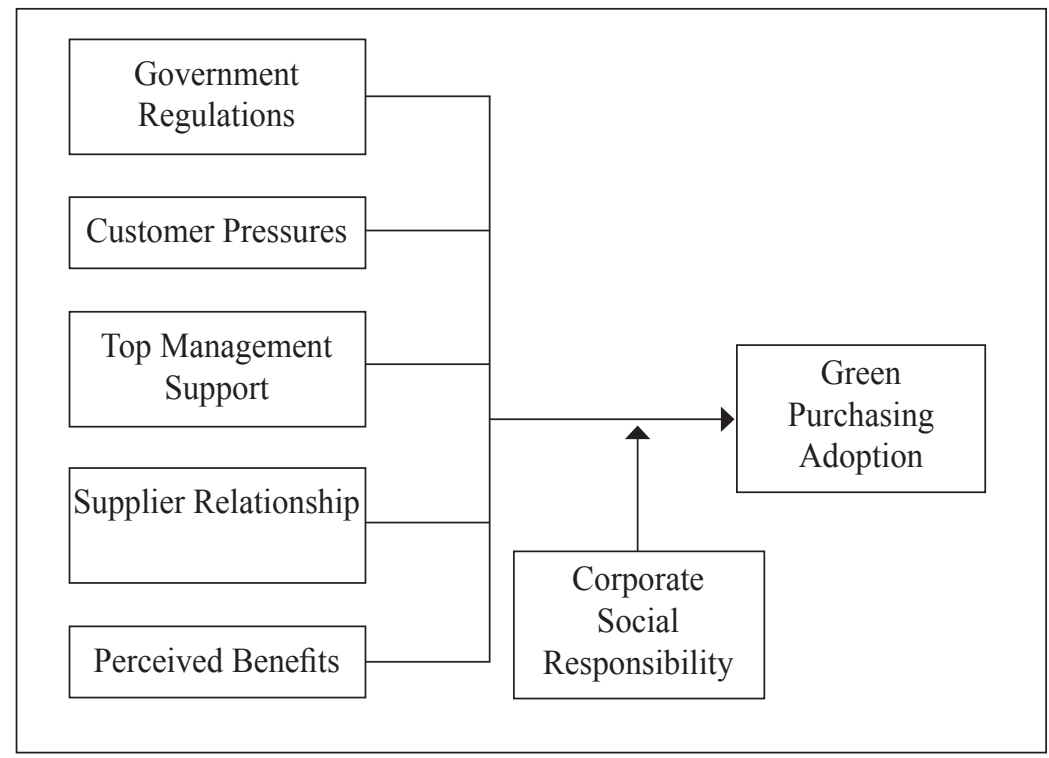

\subsection{Hypotheses Development}

Based on theoretical framework in Figure 1, the following hypotheses were developed in this study:

\section{i. Government Regulations}

Government regulations and environmental attitude can best predict GP practices (Holt \& Ghobadian, 2003). The role of government by enforcing strict regulations to be complied by firms encourage GP practices in resolving environmental issues is becoming more and more important, which is widely recognized by academics (Simpson, et al. 2007). Environmental regulation results in improved environmental procedures and green practices (Williamson et al. 2006). This is also similar to the study done by Palmer (2000), where government regulations is seen as the "main driving force for firms to adopt GP, to enhance towards environmental improvement". Accordingly, this study hypothesizes that:

H1: Government regulations have a positive and significant relationship with green purchasing adoption for SMEs in Malaysia. 


\section{ii. $\quad$ Customer Pressures}

Hall (2000) stated that customers reflect market pressures onto their suppliers which in turn enhance the GP practices. Customer pressure is regarded as the most prominent factor influencing a company's to participate in GP activities and environmental strategy (Buysse \& Verbeke, 2003; Gonzalez-Benito, 2006). Customers are the important stakeholders towards the success of GP as they were the one who require special treatment or special products. Thus, the firms need to make changes to embark on GP practices to make their customers satisfy and stay with them (ElTayeb et al. 2009). Accordingly, this study hypothesizes that:

H2: Customer pressures have a positive and significant relationship with green purchasing adoption for SMEs in Malaysia.

\section{iii. Top Management Support}

Senior and top management support, guidance and leadership are important key drivers for an organizational change towards green practices and environmental initiatives (Griffin et al. 2004; Rojšek, 2001). Top management commitment and support is vital for a successful environmental management activities (Rice, 2003; Zsidisin \& Siferd, 2001). Top management support and commitment positively and significantly impacts environmental collaboration with suppliers and demonstrates that top management support influences firm towards green purchasing adoption (Yen \& Yen, 2012). Accordingly, this study hypothesizes that:

H3: Top management support has a positive and significant relationship with green purchasing adoption for SMEs in Malaysia.

\section{iv. Supplier Relationship}

There is an increasing attention for companies to collaborate with their suppliers to integrate environmental issues into supplier selection and evaluation while adopting GP (Handfield et al. 2002; Humphreys et al. 2003; Koplin et al. 2007; Rao \& Holt, 2005). This is because the environmental performance and sustainability of a company depends on their suppliers. Zsidisin and Siferd (2001) added that this approach is to ensure that supplier processes do not contravene with the firm's environmental posture to produce products which does not contain hazardous or toxic chemicals. Accordingly, this study hypothesizes that:

H4: Supplier relationship has a positive and significant relationship with green purchasing adoption for SMEs in Malaysia.

\section{v. Perceived Benefits}

Firms are reluctant to adopt GP activities because of the high costs associated with these activities (Min \& Galle, 2001; Preuss, 2001; Rao, 2006). Therefore, only firms that foresee business benefits from these activities are motivated to adopt GP activities. This is supported by Hussain (1999) who argued that firm would choose an expensive green option if they expects profitability to increase as a result. These studies concluded that perceived benefit 
has a significant effect on GP adoption among business organization. Accordingly, this study hypothesizes that:

H5: Perceived benefit has a positive and significant relationship with green purchasing adoption for SMEs in Malaysia.

\section{vi. Corporate Social Responsibility(CSR)}

Corporate social responsibility is agreed as an environmental pillar which includes aspects such as IS0 14001, cleaner production, industrial ecology, eco-efficiency and sustainability reporting (Milton, 2008). CSR is seen as a good practice in embarking towards green purchasing initiatives and giving importance to environmental aspects (Milton, 2008). However, the practice of CSR remains low due to green practices require cost and capabilities, thus CSR only plays a moderator role towards green purchasing practices for firms (Milton, 2008; Min \& Galle, 2001). Accordingly, this study hypothesizes that:

H6 (a): The relationship between government regulation and green purchasing adoption is stronger among SMEs with greater level of corporate social responsibility.

H6 (b): The relationship between customer pressures and green purchasing adoption is stronger among SMEs with greater level of corporate social responsibility.

H6 (c): The relationship between top management support and green purchasing adoption is stronger among SMEs with greater level of corporate social responsibility.

H6 (d): The relationship between supplier relationship and green purchasing adoption is stronger among SMEs with greater level of corporate social responsibility.

H6 (e): The relationship between perceived benefit and green purchasing adoption is stronger among SMEs with greater level of corporate social responsibility.

\section{SAMPLING AND METHODOLOGY}

SMEs is defined as a manufacturing firm with 150 or fewer full time employees or RM25 million or lesser annual sales turnover. The population for this study is 175 EMS ISO 14001 certified SMEs in Malaysia that are registered under Federation of Malaysian Manufacturers (FMM) 2012 as they were expected to embark on the GP adoption. The respondents targeted and participated in this study include Chief Executive Officer (CEO), Managing Director, General Manager, Senior Managers or Environmental Management Representative (EMR) from EMS ISO 14001 certified SMEs in Malaysia that are registered under FMM 2012. The CEO, Managing Director, General Manager, Senior Managers or EMR is targeted as the respondent in this study because they are the appropriate person as they are more knowledgeable about the environmental management system or green issues compared to any others. The unit of analysis for this study is the organization or firm as to determine the factors that influence SMEs towards GP adoption. The sampling method used in this study is census in which the 
whole population of EMS ISO 14001 certified SMEs, which is 175 SMEs was contacted in the process of gathering the data. Census is defined as a research study that consists of data about or from every number of a target population and may be the ideal approach for small populations (Hair et al. 2008).

A pilot study was conducted to test on the relevance of the topic to the population and also the validity of the questions. The questionnaires were distributed to ten (10) experts from the field of Supply Chain Management in SMEs who attended a "Supply Chain Management Forum". The experts include Managing Director, Supplier Quality Engineer, Purchasing, Operation and Quality Executive from EMS ISO 14001 certified SMEs in Malaysia that are registered under FMM 2012, where they were expected to be highly informative and knowledgeable about the green issues in the firm (ElTayeb et al. 2009; Rao \& Holt, 2005). Responses received upon the pilot study proved that the questions were relevant and valid for statistical testing. This was followed by a cross-sectional approach using survey which was carried out to obtain quantitative data for statistical testing of the hypotheses. The survey questionnaires were sent to 165 EMS ISO 14001 certified SMEs under the FMM 2012. The total population of EMS IS0 14001 certified SMEs under the FMM 2012 was 175 SMEs, and the survey questionnaires were sent to 165 SMEs, excluding the 10 SMEs where the experts from respective firms have participated in the pilot study. Self-administered emailed survey questionnaire was employed in this study because of its advantage of obtaining response from a sample that is geographically dispersed, EMS ISO 14001 certified SMEs which are located throughout Malaysia in less time and with reduced costs (Sekaran, 2003). The questionnaire was adapted based on few studies (Baguette, 2009; ElTayeb et al. 2009; Rao \& Holt, 2005). A five-point Likert scale was used to measure the all the variables in this study, which is coded and described as 1 ("Strongly Disagree"), 2 ("Disagree”), 3 ("Neutral"), 4 ("Agree”) and 5 ("Strongly Agree"). Data collected was analyzed using Statistical Package for the Social Sciences (SPSS) software version 16 where selected variables are subject to statistical analysis for data analysis.

\section{FINDINGS}

\subsection{Multiple Regression Analysis}

The Multiple Regression Analysis (MRA) was used in this study to test all the hypotheses. Table 1 presents the result of MRA, where three (3) models were used to test the hypotheses. Based on model 1, when the independent were entered together with dependent variable in Model 1, the R-square value has $49.9 \%$ which is considered good as the model was able to explain $49.9 \%$ of variation in green purchasing adoption by SMEs in Malaysia, with highly significant value of, $\mathrm{p}<0.000$. As for Durbin-Watson, the value should fall in the range of 1 to 2.5 which means the error term is independent (Hair et al. 2006). In model 1, the value of Durbin-Watson is 1.716 which means the error term is relatively independent. Government regulations, customer pressures and perceived benefit were found to have positively significant relationship towards green purchasing adoption by SMEs in Malaysia, where government regulation has a beta of 0.245 , with p-value of 0.011 , customer pressures with beta value of 0.361 and p-value of 0.000 which is highly significant and perceived benefit has a beta of 0.247 and p-value of 0.05 .Thus, hypotheses H1, H2 and H5 were supported by model 1 and 
accepted in this study. Other independent variables such as top management support, with $\beta$ $=0.114, \mathrm{p}=0.148$, supplier relationship with $\beta=0.035, \mathrm{p}=0.660$ were found to have positive and insignificant relationship with green purchasing adoption by SMEs in Malaysia. Thus, hypotheses $\mathrm{H} 3$ and $\mathrm{H} 4$ were not supported by model 1 and were rejected in this study.

In model 2, when the independents variables were entered together with moderating variable and dependent variable, R-square increased to $51.8 \%$ with $\mathrm{p}$ value of 0.000 which is highly significant. In model 2, the value of Durbin-Watson is 1.648 which proves the error term is relatively independent. However, the moderating variable, CSR was found to have $\beta=0.166$, $\mathrm{p}=0.059$, which means it is positive and insignificant to influence the overall independent variables towards green purchasing adoption by SMEs in Malaysia. Although CSR was found to be insignificant, the interaction between CSR and the IVs were still examined as shown in model 3. However, the hypotheses for interaction, H6(a), H6(b), H6(c), H6(d) and H6(e) were rejected as none of the IVs were found to be positively significant towards GP with the interaction of CSR. Thus, this study concludes that CSR does not play a moderator role towards the green purchasing adoption by SMEs in Malaysia. Table 2 summarized final hypotheses results of this study.

Table 1: Result of Multiple Regressions Analysis

\begin{tabular}{|c|c|c|c|c|c|c|}
\hline \multirow{3}{*}{ Variables } & \multicolumn{6}{|c|}{ Dependent Variable : Green Purchasing Adoption } \\
\hline & \multicolumn{2}{|c|}{ Model 1} & \multicolumn{2}{|c|}{ Model 2} & \multicolumn{2}{|c|}{ Model 3} \\
\hline & $(\beta)$ & (p) & ( $\beta)$ & (p) & $(\beta)$ & (p) \\
\hline \multicolumn{7}{|l|}{ Independent Variables (IVs) } \\
\hline Government Regulations (GR) & 0.245 & $0.011^{*}$ & 0.231 & $0.015^{*}$ & 0.046 & $0.001 * * *$ \\
\hline Customer Pressures $(\mathrm{CP})$ & 0.361 & $0.000 * * *$ & 0.328 & $0.001 * * *$ & 0.785 & $0.000 * * *$ \\
\hline Top Management Support (TM) & 0.114 & 0.148 & 0.091 & 0.248 & 0.158 & 0.119 \\
\hline Supplier Relationship (SR) & 0.035 & 0.660 & 0.026 & 0.743 & 0.197 & 0.062 \\
\hline Perceived Benefits (PB) & 0.247 & $0.05^{*}$ & 0.188 & $0.038^{*}$ & 0.365 & $0.000 * * *$ \\
\hline \multicolumn{7}{|l|}{ Moderating Variable (MV) } \\
\hline \multicolumn{7}{|l|}{ Corporate Social } \\
\hline Responsibility (CSR) & & & 0.166 & 0.059 & 0.037 & 0.308 \\
\hline \multicolumn{7}{|l|}{ Interaction of IVs with MV } \\
\hline GR $x$ CSR & & & & & 1.445 & 0.106 \\
\hline CP x CSR & & & & & -1.034 & $0.000 * * *$ \\
\hline TM x CSR & & & & & -0.181 & 0.102 \\
\hline SR x CSR & & & & & -0.216 & 0.059 \\
\hline PB x CSR & & & & & -0.526 & $0.000 * * *$ \\
\hline R-Square & \multicolumn{2}{|c|}{0.499} & \multicolumn{2}{|c|}{0.518} & \multicolumn{2}{|c|}{0.993} \\
\hline $\mathrm{R}^{2}$ Change & \multicolumn{2}{|c|}{0.499} & \multicolumn{2}{|c|}{0.019} & \multicolumn{2}{|c|}{0.475} \\
\hline Durbin-Watson & \multicolumn{2}{|c|}{1.716} & \multicolumn{2}{|c|}{1.648} & \multicolumn{2}{|c|}{2.381} \\
\hline Sig. of Model (p) & \multicolumn{2}{|c|}{$0.000 * * *$} & \multicolumn{2}{|c|}{$0.000 * * *$} & \multicolumn{2}{|c|}{$0.000 * * *$} \\
\hline
\end{tabular}

Notes: ${ }^{*} \mathrm{p}<0.05(5 \%),{ }^{* *} \mathrm{p}<0.01(1 \%),{ }^{* * *} \mathrm{p}<0.001(0.1 \%)$. 
Table 2: Hypotheses Results

\begin{tabular}{|c|c|c|}
\hline Hypotheses & Statement of Hypotheses & Results \\
\hline $\mathrm{H} 1$ & $\begin{array}{l}\text { Government regulation has a positive and significant relationship } \\
\text { with green purchasing adoption for SMEs in Malaysia. }\end{array}$ & Accepted \\
\hline $\mathrm{H} 2$ & $\begin{array}{l}\text { Customer pressures have a positive and significant relationship } \\
\text { with green purchasing adoption for SMEs in Malaysia. }\end{array}$ & Accepted \\
\hline H3 & $\begin{array}{l}\text { Top management support has a positive and significant relationship } \\
\text { with green purchasing adoption for SMEs in Malaysia. }\end{array}$ & Rejected \\
\hline $\mathrm{H} 4$ & $\begin{array}{l}\text { Supplier relationship has a positive and significant relationship } \\
\text { with green purchasing adoption for SMEs in Malaysia. }\end{array}$ & Rejected \\
\hline H5 & $\begin{array}{l}\text { Perceived benefit has a positive and significant relationship with } \\
\text { green purchasing adoption for SMEs in Malaysia. }\end{array}$ & Accepted \\
\hline H6(a) & $\begin{array}{l}\text { The relationship between government regulation and green } \\
\text { purchasing adoption is stronger among SMEs with greater level } \\
\text { of corporate social responsibility. }\end{array}$ & Rejected \\
\hline H6(b) & $\begin{array}{l}\text { The relationship between customer pressures and green purchasing } \\
\text { adoption is stronger among SMEs with greater level of corporate } \\
\text { social responsibility. }\end{array}$ & Rejected \\
\hline $\mathrm{H} 6(\mathrm{c})$ & $\begin{array}{l}\text { The relationship between top management support and green } \\
\text { purchasing adoption is stronger among SMEs with greater level } \\
\text { of corporate social responsibility. }\end{array}$ & Rejected \\
\hline H6(d) & $\begin{array}{l}\text { The relationship between supplier relationship and green } \\
\text { purchasing adoption is stronger among SMEs with greater level } \\
\text { of corporate social responsibility. }\end{array}$ & Rejected \\
\hline H6(e) & $\begin{array}{l}\text { The relationship between perceived benefit and green purchasing } \\
\text { adoption is stronger among SMEs with greater level of corporate } \\
\text { social responsibility. }\end{array}$ & Rejected \\
\hline
\end{tabular}

\section{IMPLICATIONS, LIMITATIONS AND FUTURE RESEARCH DIRECTIONS}

At present, the practice of green purchasing adoption among the SMEs in Malaysia are said to be virtually non-existent as the concept is still new to many (Green Purchasing Network Malaysia, 2003). Hence, this study would be the first attempts to investigate on the factors influencing green purchasing adoption for SMEs in Malaysia. Based on the results, it is noted that government regulations, customer pressures and perceived benefit were positively significant towards green purchasing adoption. On the other hand, top management support 
and supplier relationship were found to be not significant towards green purchasing adoption. Corporate social responsibility was also not significant and does not play a moderator role in enhancing the predictor variables towards green purchasing adoption.

It is argued that SMEs can improve their environmental performance throughout the supply chain by obtaining the practical implications from this study. SMEs can be motivated to participate in green purchasing adoption following the government's initiatives in funding, tax reduction and also customer's strong requirements in meeting product standards complying with environmental standards. SMEs who are under environmental pressure and who are provided with government and customer's support are likely to participate in green practices. Besides, there are several activities recommended such as, increasing the manager's awareness through training and education, integrating environmental function and social responsibility concerns into a strategic decision making process and also putting more resources into pollution preventative solutions. This can be achieved through the co-operation of all the stakeholders that are directly and indirectly involved the in outcome of SMEs business processes. This is in-line with the stakeholders' theory which bonds all the stakeholders of firms in resolving increasing environmental issues.

Hence, the authors would like to highlight a few limitations. The number of factors examined in this study is considered limited due to the time constraint to explore other underlying factors which would influence towards green purchasing adoption. Moreover, a relatively narrow population of SMEs (with ISO EMS 14001) registered under FMM 2012, in the context of Malaysia might have created grounds for bias. Future studies are suggested to investigate the effects of other factors that motivate firms to adopt green purchasing initiatives, which have not been investigated in this study, such as competitors, community and employee pressures. Furthermore, future studies can replicate this study using larger population and samples and different contexts such as different sectors or countries.

\section{CONCLUSION}

In Malaysia, there is a lack of empirical studies that investigate the existence of green practices (ElTayeb et al. 2009). Thus, this study contributes to the literature providing an insight into the green purchasing adoption by SMEs in Malaysia. This is in-line with the practice of green purchasing among SMEs in Malaysia which is virtually non-existence, where SMEs are considered as a back bone of our country where they contribute economic performance of our country (Green Purchasing Network Malaysia, 2003; Tenth Malaysia Plan, 2010). The research findings fulfilled the research objectives and answered the research questions of this study. The level of GP adoption among SMEs in Malaysia is still low as the external forces such as government regulations and customer pressures influencing GP adoption and the internal forces influencing GP adoption was only perceived benefit.

Other internal forces such as top management support and supplier relationship does not influence the GP adoption. This is added with corporate social responsibility which does not plays a moderator role in enhancing the predictor variables, namely government regulations, customer pressures, top management support, supplier relationship and perceived benefit 
towards GP adoption for SMEs in Malaysia. This proves that the internal management of SMEs is weak and they would only embark on green practices when they receive a great pressure from external forces and when they perceive benefits from the green practices. The top management commitment and the level of environmental awareness are still low, which caused the internal management towards green practices still lack among SMEs. Furthermore, SMEs perceive societal responsibility would minimize the profit of their business. This attitude should be polished where SMEs should strengthen their commitment and responsibility in practicing green initiatives and giving societal concerns in their business processes.

\section{REFERENCES}

2013 Budget Forum. (2012). Prospering the Nation, Enhancing Well-Being of the Rakyat : A Promise Fulfilled. Ministry of Finance.

Baguette, B. (2009). Insights on SMEs embracing sustainability: A descriptive analysis of the environmental role of purchasing in Walloon SMEs. Maastricht University, School of Business and Economics. Maastricht: Maastricht University.

Bowen, F. E., Cousins, P. D., Lamming, R. C., \& Farukt, A. C. (2001).The role of supply management capabilities in green supply. Production and Operations Management, 10(2), 174-189.

Buysse, K., \& Verbeke, A. (2003). Proactive Environmental Strategies: A Stakeholder Management Perspective. Strategic Management Journal, 24(5), 453-470.

Chien M. K., \& Shih L. H. (2007). An empirical study of the implementation of green supply chain management practices in the electrical and electronic industry and their relation to organizational performances. Int. J. Environ. Sci. Tech, 4(3), 383-394.

Doonan, J., Lanoie, P., \& Laplante, B. (2005). Analysis determinants of environmental performance in the Canadian pulp \& paper industry: an assessment from inside the industry. Ecological Economics, 55(1),73-84.

Duber-Smith, D. C. (2005). The Green Imperative. Soap, Perfumery, and Cosmetics, 78(8), 24-26.

ElTayeb, T. K., Zailani, S., \& Jayaraman, K. (2009). The examination on the drivers for green purchasing adoption among EMS 14001 certified companies in Malaysia. Journal of Manufacturing Technology Management, 21(2), 206-225.

Evan, W. M., \& Freeman, R. E. (1990). Corporate Governance: A stakeholder Interpretation. Journal of Behavioral Economics, 19(4), 337-359.

Fontaine, C., Haarman, A., \& Schmid, S. (2006). The Stakeholder Theory. Retrived February 10, 2012, from http://edalys.fr/documents/Stakeholders\%20theory.pdf

Forman, M., \& Jorgensen, M. S. (2004). Organizing environmental supply chain management. Greener Management International, 45, 43-62. 
Freeman, R. E. (2004). A Stakeholder Theory of Modern Corporations. In T. L. Beauchamp, ed \& N.E. Bowie (Eds), Ethical Theory and Business(7th edn). Upper Saddle River, NJ: Prentice Hall.

Friedman, A. L., \& Miles, S. (2006). Stakeholders: Theory and Practice. New York: Oxford University Press.

Ghobadian, A., Viney, H., \& Holt, D. (2001). Seeking congruence in implementing corporate environmental strategy. International Journal of Environmental Technology and Management, 1(4), 384-401.

Goh, E. A., Zailani, S., \& Wahid, N. A. (2006). A study on the impact of environmental management system (EMS) certification towards firms' performance in Malaysia. Management of Environmental Quality: An International Journal, 17(1),73-93.

Goh, Y. N. (2011). Determining Factors for ISO14001 EMS Implementation among SMEs in Malaysia: A Resource Based View. International Journal of Social, Human Science and Engineering,5(11), 43-46.

Goh, Z. W., \& Zailani, S. (2010). Green Supply Chain Initiatives: Investigating on the Barriers in the Context of SMEs in Malaysia. International Business Management, 4(1), 20-27.

Gonzalez-Benito, J. (2006). A Review of Determinant Factors of Environmental Proactivity. Business Strategy and the Environment, 15(2), 87-102.

Green Purchasing Network Malaysia. (2003). An Introductory Study on Green Purchasing Activities in Malaysia. Kuala Lumpur: Green Purchasing Network Malaysia.

Griffin, M. A., Rafferty, A. E., \& Mason, C. M. (2004). Who started this? Investigating different sources of organizational change. Journal of Bussiness Psychology, 18(4),555-570.

Gunther, M. (2006). The Green Machine. Fortune Magazine.

Hair, J. F., Anderson, R., Tatham, R., \& Black, W. (2006). Multivariate Data Analysis. Upper Saddle River: Prentice-Hall.

Hair, J. F., Wolfinbarger, M., Ortinau, D. J., \& Bush, R. P. (2008). Essentials of Marketing Research. 1st Edition. New York: McGraw-Hill.

Hall, J. (2000). Environmental supply chain dynamics. Journal of Cleaner Production, 8(6), 455-471.

Handfield, R., Sroufe, R., \& Walton, S. (2005). Integrating environmental management and supply chain strategies. Business Strategy and the Environment, 14,1-19.

Handfield, R., Walton, S. V., Sroufe, R., \& Melnyk, S. A. (2002). Applying environmental criteria to supplier assessment: a study in the application of the analytical hierarchy process. European Journal of Operational Research, 14(16), 70-87. 
Holt, D., \& Ghobadian, A. (2003). Greening the Supply Chain-Critical Factors Driving Operational Activity. Paper presented at Innovating for Sustainability October 12-15, $200311^{\text {th }}$ International Conference of Greening of Industry Network, San Francisco.

Holt, D., \& Ghobadian, A. (2009). An empirical study of green supply chain management practices amongst UK manufacturers. Journal of Manufacturing Technology Management, 20(7), 933-956.

Hsu, C. W., \& Hu, A. H. (2008). Green Supply Chain Management in the Electronic Industry. Int. J. Environ. Sci. Tech., 5(2), 205-216.

Hsu, C. W., \& Hu, A. H. (2010). Critical factors for implementing green supply chain management practice. Management Research Review, 33(6), 586-608.

Humphreys, P. K., Wong, Y. K., \& Chen, F. T. S. (2003). Integrating environmental criteria into the supplier selection process. Journal of Materials Processing Technology, 138(13), 349-356.

Hussain, S. S. (1999). The ethics of 'going green': the corporate social responsibility debate. Business Strategy and the Environment, 8(4), 203-210.

Koplin, J., Seuring, S., \& Mesterharm, M. (2007). Incorporating sustainability into supply management in the automotive industry - the case of the Volkswagen AG. Journal of Cleaner Production, 15(11/12),1053-1062.

Lee, C. K., \& Chen, S. H. (2010). Selecting the most feasible strategy for green supply-chain management. The Business Review Cambridge, 14(2),141-146.

Lee, S. Y. (2008). Drivers for the participation of small and medium-sized suppliers in green supply chain initiatives. Supply Chain Management: An International Journal, 13(3), 185-198.

Lin, C. Y. (2007). Adoption of green supply chain practices in Taiwan's logistics industry. Journal of International Management Studies, 2(2), 90-98.

Lin, C. Y., \& Ho, Y. H. (2011). Determinants of Green Practice Adoption for Logistics Companies in China. Journal of Business Ethics, 98, 67-83

Logamuthu, \& Zailani, S. (2010). Factors Influencing the Implementation of Green Productivity Practices and its Effect on the Organisational Performance: A Comparison Study Between EMS 14001 and ISO 9000 Certified Companies in Malaysia. Asian Journal of Information Technology, 9(2), 45-53.

Milton, S. (2008). The Environmental Manager and Corporate Social Responsibility. Paper presented at $2^{\text {nd }}$ Environmental Management Leadership Symposium, Peradeniya, Sri Lanka.

Min, H., \& Galle, W. P. (2001). Green purchasing practices of US firms. International Journal of Production and Operations Management, 21(9), 1222-1238. 
Murphy, P. R., \& Poist, R. F. (2003). Green perspectives and practices: a 'comparative logistics'study. Supply Chain Management: An International Journal, 8(2), 122-131.

Ninlawan, C., Seksan, P., Tossapol, K., \& Pilada, W. (2010). The Implementation of Green Supply Chain Management Practices in Electronics Industry. Proceedings of the MultiConference of Engineers and Computer Scientist, Vol III, IMECS 2010, March 17-19, 2010, Hong Kong.

Palmer, J. (2000). Helping SMEs Improve Environmental Management. In R. Hillary (Eds.), Small and medium-sized enterprises and the environment (pp.325-342). Sheffield: Greenleaf.

Peng, Y. S., \& Lin, S. S. (2008). Local responsiveness pressure, subsidiary resources, green management adoption and subsidiary's performance: evidence from Taiwanese manufactures. Journal of Business Ethics, 79(1), 199-212.

Preuss, L. (2001). In dirty chains? Purchasing and greener manufacturing. Journal of Business Ethics, 34(3), 345-359.

Rao, P. (2006). Greening of suppliers/in-bound logistics in the South East Asian context. In J. Sarkis (Eds.), Greening the Supply Chain (pp. 189-204). London: Springer.

Rao, P., \& Holt, D. (p). Do green supply chains lead to competitiveness and economic performance?. International Journal of Operations \& Production Management, 25(9), 898-916.

Rice, S. (2003). Commitment to excellence: practical approaches to environmental leadership. Environmental Quality Management, 12(4), 9-22.

Rojšek, I. (2001). From red to green: Towards the environmental management in the country in transition. Journal of Business Ethics, 33(1), 37-50.

Salam, M. A. (2008). Green procurement adoption in manufacturing supply chain. Proceedings of the $9^{\text {th }}$ Asia Pasific Industrial Engineering and Management Systems Conference (APIEMS2008), 3-5 December 2008, Indonesia., 1253-1260.

Sarkis, J., Zhu, Q., \& Lai, K.-H. (2010). An Organizational Theoretic Review of Green Supply Chain Management Literature. International Journal of Production Economics, 130(1), $1-15$.

Sekaran, U. (2003). Research Methods for Business: A Skill Building Approach. Singapore: Wiley.

Simpson, P, D., \& Samson, D. (2007). Greening the Automotive Supply Chain: A Relationship Perspective. International Journal of Operations and Production Management, , 27(1), $28-48$.

Srivastara, S. K. (2007). Green Supply-Chain Management: A State-of-The-Art Literature Review. International Journal of Management Reviews, 9(1), 53-80. 
Stevels, A. (2002). Green Supply Chain Management Much More Than Questionnaires and ISO 14.001. IEEE, 96-100.

Tenth Malaysia Plan. (2010). Chapter 3: Creating the Environment and Unleashing the Economic Growth. Putrajaya: The Economic Planning Unit, Prime Minister's Department.

Walton, S. V., Handfield, R. B., \& Melnyk, S. T. (1998). The green supply chain: integrating suppliers into environmental management process. International Journal of Purchasing and Materials Management, 34(1), 2-11.

Williamson, D., Lynch-Wood, G., \& Ramsay, J. (2006). Drivers of Environmental Behaviour in Manufacturing SMEs and the Implications for CSR. Journal of Business Ethics, 67, $317-330$.

Yen, Y. X., \& Yen, S. Y. (2012). Top-management's role in adopting green purchasing standards in high-tech industrial firms. Journal of Business Research, 65(7), 951-959.

Zhu, Q., \& Geng, Y. (2001). Integrating environmental issues into supplier selection and management a study of large and medium-sized state owned enterprises in China. Greener Management International, 35, 27-40.

Zsidisin, G. A., \& Siferd, S. P. (2001). Environmental purchasing: a framework for theory development. European Journal of Purchasing \& Supply Management, 7(1),61-73. 